\title{
Does Model Reflect on Reality? Exploring Beneish M Score on Selected Private Commercial Banks in Nepal
}

\author{
Santosh Gyawali, $\mathrm{PhD}^{*}$
}

DOI: https://doi.org/10.3126/jnbs.v14i1.41485

Received on 8 April 2021

Accepted on 2 November 2021

\begin{abstract}
This research explores if possible fraudulent financial statement is present in private commercial banks in Nepal. This study examines the viability of Beneish M-score model in detecting probable earning manipulation considering the sample of 16 private commercial banks including the joint ventures. The published annual report (income statement and balance sheet) of the year 2018 and 2019 of respective banks are used as a secondary source of information. This research employs Beneish M-score equation and threshold value -2.22 as keys to analysis. The result shows even four banks are engaging in income manipulation, the Beneish model cannot identify the deception on the financial statement. Though the given model is suggested for manufacturing companies, the researcher has used it to explore the Banks-this is the limitation of this research. Further investigation of these tools combined with other fraud detection models is suggested to discover financial manipulation and relationship with the stock market return.
\end{abstract}

Keywords: Beneish M-score, earning manipulation, income statement, financial fraud, private commercial banks

\section{INTRODUCTION}

Financial deception is an important concern to an organization and its overlook may cause financial as well as non-financial losses. Wells (2017) delineates fraud or manipulation as the intention of dishonesty or failure in regulatory frameworks to hurt the victims. Nepal Standards on Auditing (NSA) labels fraud as intended action by management, employees, or by third parties, engaging in deception for unjust or illegal benefits ("Occupational fraud and Nepalese scenario", 2020). The Association of Certified Fraud Examiners (ACFE, 2016) characterizes fraud as "the deliberate action or falsification of the material financial facts of an entity committed by intentionally forging or omitting the facts or disclosures in the financial statements to purposefully deceive the users of financial statements." Financial fraud is also named fraudulent financial reporting that is a type of fraud that instigates misreporting in financial statements. Further, the ACFE's Report to the Nations 2020, states financial statement fraud happened only in 10 percent of entire fraud cases investigated from January 2018 to September

\footnotetext{
${ }^{*}$ Mr. Gyawali is an Assistant Professor at Butwal Multiple Campus, Faculty of Management, Tribhuvan University. Email: santwmc@gmail.com
} 
2019 with a median loss of US\$ 954,00 (“Association of certified fraud examiners", 2020). Considering the Nepalese Context, Financial Fraud Conference organized on May 7, 2018, in the capital city Kathmandu reported: "178 financial crimes worth NPR 36 billion have been registered in Nepal in the last eight years." The database of Nepal Police documented 368 incidents related to financial deception in the entire country in the fiscal year 2016/17. In the year 2017/18, the statistics mounted to 542. In the year 2018/19, police enlisted 627 fraud-related cases ("Kathmandu Post," 2019) but these statistics do not represent the share of fraudulent financial reporting by the corporations. Private companies or even public companies have opportunities for profit manipulation. Firth, Rui and Wu (2010); and Perols and Lougee (2011) claim that the firms with financial losses have great motivation to engage in fraud than those firms which are financially superior.

Cressey (1973) detected major three determinants of financial statement fraud; motivation (situational pressures to management that stimulate to make fraud), opportunity (apparent opportunities that motivate to perform fraud act or screening of dishonesty related action) and rationalization (rationalizing the action as justifiable by some means). Malpractice in financial reporting practices or fraudulent financial reporting might cause considerable harm to investors. Sridharan, Caines, McMillan and Summers (2002) support this argument and claim after the announcement of Enron's fraudulent financial activities, its share prices slumped to record paper loss of US $\$ 90$ billion to its shareholders. The tolerance of financial fraud or manipulation results in the cost of losing share prices (Lee \& Lo, 2016), losing reputation (Efendi et al. 2007), losing investors' confidence (Beneish \& Nichols, 2007). Repousis (2016) suggests the view, by making fraudulent financial reports; the management, in the short run, may maintain their managerial image, assure better stock prices, meet the company's projections as well as investor expectations.

Beneish (1999) developed eight variables model that is called Beneish Model or Beneish M-score, to discover the tendency of earning manipulation or to identify the incidents of financial fraud. Afterward, Beneish and Nichols (2009) extend this model to verify the likelihood of financial statement manipulation in two alternatives which comprise eight and five variables. The Beneish model is attempted to uncover unethical and illegal exercises revealed in business corporations. Major financial scams in the US like Enron and WorldCom, similarly Pacific Electric Wire \& Cable, Procomp, Infodisc Technology, and Simmit Technology in Taiwan, manifested in the early 2000s (Chen, 2016). In such regard, this model could support the management to confirm if the financial statements of the company had irregularities or frauds to prevent the organization from future potential backlash.

Beneish (1999) performed a quasi-experimental research design to detect the financial fraudulent behavior of publicly traded companies. The author considered the sample of 74 earning manipulators companies and 2332 non-manipulators. The sample companies were selected during the year 1982 to 1988 periods and finally, it had 50 manipulators and 1,708 controls for the observation. The evidence presented in the research study was based on sample companies whose earning manipulation was publicly disclosed. The recent study has adopted a descriptive research design with intention of exploring the authenticity of the Beneish model in selected Nepalese commercial banks since Beneish's original research work was excluded the banks. Similarly, this study has attempted to explore the financial manipulation of selected banks even though their manipulation of earning was not publicly discovered. Beneish (1999) carried out his study by occupying a large number of samples and developed the model, however, this research has the aim of testing that developed model.

M-Score proved to be a successful predictor of 76 percent of the reported cases of manipulation by the Security and Exchange Commission (Kamal, Salleh, \& Ahmad, 2016). 
Maccarthy (2017) suggests the Beneish M-Score model that forecasts the possibility of manipulation of financial reports by firms and can be implemented as a complementary tool with Altman Z-score for forensic accounting investigations. In the case of the empirical investigation, Anh and Linh (2016) advocate Beneish M-Score is a powerful fraud detection tool ensuring the least error rate. The research investigation of Tarjo and Herawati (2015) identified the Beneish model as a strong tool that identifies more than 77 percent of fraudulent firms.

In Toshiba Company, Bhavani and Amoinsah (2017) employed Beneish M-score and Altman Z-score to detect if any accounting fraud in formal financial statements. The result showed the inefficiency of the Beneish model to detect manipulations in financial statements, controversially the Altman Z- score model presented few indications about misreporting of financial statements. Kukreja et al. (2020) estimated the effectiveness of Altman Z-score and Beneish M-score models for assessing misstatements in financial records of media analytics firm named Comscore in the USA and found the Altman Z-score model as better to predict financial fraud compared to the Beneish M-score model. This finding marked several questions about the efficacy of the Beneish model that was claimed as one of the frauds predicting tools. Lotfi and Chadegani (2017) conducted the research study considering 137 samples companies enlisting in Tehran Stock Exchange within the year 2005 to 2015. They performed logistic regression and test research hypothesis at 95 percent level of confidence and found that despite a valid theoretical foundation the Beneish M-score model could not mark any signal of financial fraud in companies.

Observing these controversial results of different works of literature, it is still in dilemma that Beneish M-score model could identify the fraudulent financial reporting practices in business corporations. So, the recent research work focuses on the research question: whether or not the Beneish M-Score Model can detect frauds in financial statements of selected private commercial banks listed in the Nepal Stock Exchange?

This study focuses on the feasibility of the Beneish M-score model to detect if any earning manipulation exists. A total sample of 16 private commercial banks is in the spotlight for the research.

\section{REVIEW OF LITERATURE}

Financial reporting, earning management have been a subject of concern to the relevant stakeholders. Those practices consequently led to a total collapse of affected firms, loss of jobs and loss of investment (Abdullahi \& Ibrahim, 2017). Albashrawi (2016) observed the frequency of publication of financial fraud-related research articles, the author's meta-analysis shows almost 65 percent of total articles regarding this topic were contributed by the countries like the United States, Spain, Taiwan and China. Particularly, the United States solely had a contribution over 35 percent of the papers published. It is still in the infancy stage of research whether in South Asian academia so justifiable to research private commercial banks in Nepal.

Pravin (2020) investigated the earning management practices in Bangladesh considering 105 manufacturing companies including pharmaceuticals and chemicals, cement, food and allied engineering, textile and clothing, ceramics, tannery, jute, paper and printing, fuel and power and many others. The author used the Beneish M-score model to detect earning management and observed a larger percentage of non-manipulating companies compared to manipulators percentage of non- manipulator companies is greater than manipulator companies except paper and printing, cement and jute industry. Anning and Adusei (2020) performed the research study to explore financial statement manipulation possibilities for the years 2008-2017 amongst 19 trading and manufacturing firms listed in Ghana Stock Exchange. The authors used the Beneish model and observed, a large number of firms are possibly engaged in fraudulent financial reporting. Regarding Pescanova, the bankrupted Spanish Food Company, Orellana and colleagues (2017) 
applied Beneish Model considering the data of four consecutive years. Authors found, previous to the bankruptcy, Pescanova manipulated the total accruals to total assets (TATA) as well as the days' sales in the receivable index (DSRI). Similarly, they further claimed strong support for Beneish Model.

Akra and Chaya (2020) explored the reliability of the Beneish model apart from banking and insurances in the Kuwaiti Stock Market. Their results revealed the less predictive strength of Altman Z score than of Beneish M-score to discover probable earning manipulation or fraudulent financial reporting. In support of the Beneish M-Score model, Beneish et al. (2012) argued that the model can be implemented to detect the propensity of deception on financial statements and most empirical examples show the companies having higher M-Score than its threshold value have a greater possibility to engage in fraud. This model utilizes financial ratios of five or eight variables in detecting the possibilities of manipulation in earning. Those variables are made from the financial statement of the related companies and calculated M-score to identify the intensity of earnings manipulation. The score points greater than -2.22 imply a strong propensity for financial statements manipulation (Roxas, 2011). This is a probabilistic model so the huge limitation is that its result is not fully accurate in course of detecting fraud.

Repousis (2016) scrutinized data of the year 2011 and 2012 of 25,468 Greece companies and traced around one-third of sample companies $(8,486)$ had Beneish M-score greater than 2.22, which signaled the manipulation of financial statements. The author further suggested this tool as reliable for fraud detection. Kaur, Sharma and Khanna (2014) carried out the research study considering 332 Indian companies as a sample from the year 2011 to 2013 and got the proof that in course identifying earning manipulation, the use of Beneish M-score is comparatively better than the use of Modified Jones in detecting earnings manipulation. Omar et al. (2014) carried out the study on Megan Media Holdings Berhad (MMHB) in Malaysia and found Beneish M-score as an effective tool in the identification of fraudulent financial reporting checking its reliability at the year of misstatement. Maniatis (2021) conducted the study to detect if any financial report manipulation on Athens Stock Exchange Market enlisted 40 companies applying Beneish M-score and found 33 companies had their M-score values less than -2.22 , which meant those were not practicing financial fraudulent activities whereas 7 companies identified as possibly manipulate their earnings.

This study has the purpose to explore the ability of the Beneish M-Score Model to identify the fraudulent financial reports of selected commercial banks.

\section{METHODOLOGY}

This research has tried to explore financial fraud based on published financial reports of the selected commercial banks in Nepal. Beneish M-score model is a promising model which is extensively used by academia, auditing agencies, certified fraud examiners as well as by investment professionals (Anh \& Linh, 2016). The deductive approach has been applied to test the applicability of the Beneish model in recent research. Sample of 16 private commercial banks (Nabil Bank, Bank of Kathmandu, Everest Bank, Himalayan Bank, NMB Bank, NIC ASIA Bank, Global IME Bank, Nepal Bangladesh Bank, Nepal Investment Bank, Mega Bank Nepal, Nepal SBI Bank, Prime Commercial Bank, Standard Charted Bank, Kumari Bank, Laxmi Bank and NCC Bank) in Nepal was chosen for the study. The published annual report (income statement and balance sheet) of the year 2018 and 2019 of respective banks are used as a secondary source of information.

The recent study considered data relating to revenues, cost of goods sold, selling general and administrative expenses, depreciation, net income from continuing operations, accounts 
receivables, current assets, property plant and equipment, securities (securities is also referred to as long term investments), total assets, current liabilities, total long term debt and cash flow from the operations of two consecutive years 2018 (t-1) and 2019 (t) for acquiring DSRI (Days' Sales in Receivables Index), AQI (Asset Quality Index), GMI (Gross Margin Index), AQI (Asset Quality Index), SGI (Sales Growth Index), DEPI (Depreciation Index), LVGI (Leverage Index), SGAI (Sales General and Administrative expenses Index) and TATA (Total Accruals to Total Assets).

Beneish's (1999) M-score consists of 8 ratios to describe financial statement deformation resulting from earnings manipulation or identifying management preferences in earnings manipulation. Mantone (2013) views M-score as the tool to portray the amount of likelihood of earning manipulation and other fraudulent activities. Warshavsky (2012), Mantone (2013) and Omar et al. (2014) suggest a total M-score higher than -2.22 is taken as a signal of potential manipulation in earnings and fraudulent financial reporting.

$$
\begin{gathered}
M-\text { Score }=-4.84+0.92 D S R I+0.528 G M I+0.404 A Q I+0.892 S G I+0.115 D E P I \\
-0.172 S G A I+4.679 T A T A-0.327 L V G I
\end{gathered}
$$

DSRI (Days' Sales in Receivables Index): This measures the ratio of days' sales in receivables versus prior year as an indicator of revenue inflation.

$$
\frac{\text { Receivables }(t) / \text { Sales }(t)}{\text { Receivables }(t-1) / \text { Sales }(t-1)}
$$

GMI (Gross Margin Index): This is measured as the ratio of gross margin versus prior year. A firm with poorer prospects is more likely to manipulate earnings.

Sales $(t-1)-$ Cost of goods sold $(t-1) / \operatorname{Sales}(t-1)$

$$
\text { Sales }(\mathrm{t}) \text { - Cost of goods sold }(\mathrm{t}) / \operatorname{Sales}(\mathrm{t})
$$

AQI (Asset Quality Index): Asset quality is measured as the ratio of non-current assets other than plant, property and equipment to total assets, versus the prior year. It intends to measure the company's risk propensity to capitalize cost.

$\frac{[1-\text { Current Assets }(\mathrm{t})+\text { PP\&E( } \mathrm{t})] / \text { Total Assets }(t)}{[1-\text { Current Assets }(\mathrm{t}-1)+\operatorname{PP} \& E(\mathrm{t}-1)] / \text { Total Assets }(\mathrm{t}-1)}$

SGI (Sales Growth Index): This measures the ratio of sales versus prior year. While sales growth is not itself a measure of manipulation, the evidence suggests that growth companies are likely to find themselves under pressure to manipulate in order to keep up appearances.

$$
\frac{\text { Sales }(t)}{\operatorname{Sales}(t-1)}
$$

DEPI (Depreciation Index): This is measured as the ratio of the rate of depreciation versus the prior year. A slower rate of depreciation may mean that the firm is revising useful asset life assumptions upwards or adopting a new method that is income friendly.

Depreciation $(\mathrm{t}-1) /[$ Depreciation $(\mathrm{t}-1)+\mathrm{PP} \& E(\mathrm{t}-1)]$

Depreciation $(\mathrm{t}) /[$ Depreciation $(\mathrm{t})+\mathrm{PP} \& E(t)]$

SGAI (Sales General and Administrative expenses Index): This measures the ratio of SGA expenses to the prior year. This is used on the assumption that analysts would interpret a disproportionate increase in sales as a negative signal about firms' future prospects.

Sales, General and Administrative $(t) / \operatorname{Sales}(t)$

$\overline{\text { Sales, General and Administrative Expenses }(t-1) / \operatorname{Sales}(t-1)}$ 
LVGI (Leverage Index): This measures the ratio of total debt to total assets versus prior year. It is intended to capture debt covenant incentives for earnings manipulation

$\frac{[\operatorname{LTD}(\mathrm{t})+\text { Current liabilities }(\mathrm{t})] / \text { Total Assets }(\mathrm{t})}{[\mathrm{LTD}(\mathrm{t}-1)+\text { Current liabilities }(\mathrm{t}-1)] / \text { Total Assets }(\mathrm{t}-1)}$

TATA (Total Accruals to Total Assets): This assesses the extent to which managers make discretionary accounting choices to alter earnings. Total accruals are calculated as the change in working capital accounts other than cash less depreciation. It measures a risk relating to accrual policies being used as financing mechanism for losses.

$\Delta$ Current Assets $(\mathrm{t})-\Delta \operatorname{Cash}(\mathrm{t})-\Delta$ Current liabilities $(\mathrm{t})-\Delta$ Current maturities of LTD $(\mathrm{t})$

$-\Delta$ income tax payable $(\mathrm{t})-$ Depreciation and amortization $(\mathrm{t})$

Total Assets

Table 1 explains the meaning of different ratios that estimate the probability of manipulation.

\section{Table 1}

Beneish Ratios

\begin{tabular}{|c|c|}
\hline Ratios & Meaning \\
\hline DSRI & $\begin{array}{l}\text { "These variable gauges whether receivables and revenues are in or out of balance in } \\
\text { two consecutive years, this large increase in DSRI to be associated with a higher } \\
\text { likelihood that revenue and earnings are overstated" (Beneish, 1999, p. 26). }\end{array}$ \\
\hline GMI & $\begin{array}{l}\text { "When the GMI is greater than } 1 \text {, gross margins have deteriorated. Lev and } \\
\text { Thiagarajan suggested that deterioration of gross margin is a negative signal about a } \\
\text { company's prospects" (Beneish, 1999, p. 26). }\end{array}$ \\
\hline AQI & $\begin{array}{l}\text { "If the AQI is greater than 1, the company has potentially increased its involvement } \\
\text { in cost deferral" (Beneish, 1999, p. 27). }\end{array}$ \\
\hline SGI & $\begin{array}{l}\text { "Growth does not imply manipulation, but growth companies are viewed by } \\
\text { professionals as more likely than other companies to commit financial statement } \\
\text { fraud because their financial positions and capital needs put pressure on managers to } \\
\text { achieve earnings targets" (Beneish, 1999, p. 27). }\end{array}$ \\
\hline DEPI & $\begin{array}{l}\text { "A DEPI greater than } 1 \text { indicates that the rate at which assets are being depreciated } \\
\text { has slowed-raising the possibility that the company has revised upward the } \\
\text { estimates of assets' useful lives or adopted a new method that is income increasing" } \\
\text { (Beneish, 1999, p. 28). }\end{array}$ \\
\hline SGAI & $\begin{array}{l}\text { "Analysts interpret a disproportionate increase in sales as a negative signal about a } \\
\text { company's prospects" (Beneish, 1999, p. 28). }\end{array}$ \\
\hline LVGI & $\begin{array}{l}\text { "The LVGI is the ratio of total debt to total assets in year } t \text { relative to the } \\
\text { corresponding ratio in year } t-1 \text {. An LVGI greater than } 1 \text { indicates an increase in } \\
\text { leverage" (Beneish, 1999, p. 28). }\end{array}$ \\
\hline TATA & $\begin{array}{l}\text { "Total accruals were used in prior work to assess the extent to which managers make } \\
\text { discretionary accounting choices to alter earnings. It is expected higher positive } \\
\text { accruals (less cash) to be associated with a higher likelihood of earnings } \\
\text { manipulation" (Beneish, 1999, p. 28). }\end{array}$ \\
\hline
\end{tabular}


Beneish (1999) has suggested different threshold values for different ratio indexes (DSRI, AQI, GMI, SGI, LVGI, DEPI, SGAI and TATA) based on his research study over manipulating organizations and non-manipulating (controlled) organizations.

Table 2

Beneish Threshold Values for Ratios

\begin{tabular}{lll}
\hline Ratio Index & Manipulators & Non- Manipulators (controlled) \\
\hline DSRI & 1.465 & 1.031 \\
GMI & 1.193 & 1.041 \\
AQI & 1.254 & 1.039 \\
SGI & 1.607 & 1.134 \\
DEPI & 1.077 & 1.001 \\
SGAI & 1.041 & 1.054 \\
LVGI & 1.111 & 1.037 \\
TATA & 0.031 & 0.018 \\
\hline
\end{tabular}

Source: Beneish (1999, p.27)

Table 2 exhibits the Beneish threshold values for different ratio indexes. Beneish (1999), suggests the positive relationship between DSRI and earning, GMI and earning manipulation, AQI and earning manipulation, SGI and earning manipulation, DEPI and earning manipulation, SGAI and earning manipulation and TATA and earning manipulation.

\section{RESULTS AND DISCUSSION}

A recent study has tried to explore the Beneish $\mathrm{M}$ score model on private commercial banks in Nepal. The calculation of Beneish M score requires the data regarding DSRI, GMI, AQI, SGI, DEPI, SGAI, TATA and LVGI.

Table 3 displays the status of different indexes of Beneish model similarly the calculation of M Score for the 16 sample banks. Comparing the Beneish's threshold value (Table 2) for DSRI, GMI, AQI, SGI, DEPI, SGAI, LVGI and TATA with the respective calculated value of particular banks (Table 3), it reveals that Bank $\mathrm{M}$ has the highest $\mathrm{M}$-score (-1.81) with its GMI value 1.23 that breach the optimal threshold value 1.041 and can observe GMI is higher even comparing to manipulating firms (1.193). Beneish (1999) put forwards his opinion as “......when the GMI is greater than 1, gross margins have deteriorated. Lev and Thiagarajan suggested that deterioration of gross margin is a negative signal about a company's prospects" (p.26). GMI value 1.23 indicates the declining of gross margin and it could adversely affect organizations' growth potential, and the organization is engaged in earning manipulation. Similarly, Beneish further opines "....if companies with poorer prospects are more likely to engage in earnings manipulation; I expected a positive relationship between GMI and the probability of earnings manipulation" (p.26). The M Score value -1.81 which is significantly higher than of optimum threshold value -2.22 and the GMI value of 1.23 which is higher compared to the best possible threshold value 1.04 proves that there is a positive relationship between GMI and probability of earning manipulation. So, bank $\mathrm{M}$ is engaged in fraudulent financial reporting.

Concerning Bank O, Bank P, Bank J, Bank L and Bank B their respective SGAI values are 1.14, 1.04, 1.06, 1.18 and 1.09; which are greater than the threshold of 1.04. Similarly, the Mscore values are $-2.31,-2.26,-2.31,-2.41$ and -2.57 respectively. This shows, respective M-score value is less than the benchmark of -2.22. Beneish (1999) hints about SGAI as" The use of SGAI follows the recommendation of Lev and Thiagarajan those analysts interpret a disproportionate 
increase in sales as a negative signal about a company's prospects. I expected to find a positive relationship between the SGAI and the probability of manipulation" (p.27). Observing the individual SGAI with an M-score value, it could not find the relationship between those two variables. Bank O, Bank P, Bank J, Bank L and Bank B are not practicing fraud financial reporting besides of their controversial SGAI value. In this regard, the researcher cannot agree with Beneish assumption of SGAI and M-score.

Table 3

DSRI, GMI, AQI, SGI, DEPI, SGAI, TATA, LVGI and M Score values of Sample Banks

\begin{tabular}{cccccccccc}
\hline Name of Banks & DSRI & GMI & AQI & SGI & DEPI & SGAI & LVGI & TATA & M Score \\
\hline Bank A & 0.88 & 1.17 & 1.00 & 1.34 & 0.79 & 0.90 & 1.01 & 0.030 & -2.35 \\
Bank B & 1.04 & 1.11 & 0.21 & 1.08 & 0.60 & 1.09 & 1.00 & 0.029 & -2.57 \\
Bank C & 0.99 & 1.15 & 1.01 & 1.07 & 0.87 & 0.96 & 1.01 & -0.030 & -2.51 \\
Bank D & 0.87 & 1.02 & 0.93 & 1.20 & 1.06 & 1.00 & 1.00 & -0.010 & -2.48 \\
Bank E & 0.96 & 0.87 & 1.00 & 1.27 & 0.86 & 1.03 & 1.03 & 0.010 & -2.35 \\
Bank F & 0.87 & 0.86 & 0.97 & 1.43 & 0.85 & 0.98 & 0.97 & -0.020 & -2.41 \\
Bank G & 1.04 & 0.87 & 0.98 & 1.18 & 1.05 & 0.98 & 1.03 & 0.050 & -2.12 \\
Bank H & 1.01 & 0.87 & 1.00 & 1.28 & 2.57 & 0.99 & 1.04 & 0.050 & -1.91 \\
Bank I & 0.95 & 1.05 & 1.16 & 1.10 & 0.94 & 1.03 & 1.18 & -0.010 & -2.44 \\
Bank J & 0.81 & 0.97 & 0.99 & 1.56 & 0.77 & 1.06 & 1.02 & -0.020 & -2.31 \\
Bank K & 0.95 & 1.10 & 1.00 & 1.24 & 0.94 & 0.97 & 1.01 & 0.050 & -2.01 \\
Bank L & 0.94 & 0.85 & 1.00 & 1.15 & 1.06 & 1.18 & 0.99 & 0.020 & -2.41 \\
Bank M & 0.91 & 1.23 & 1.00 & 1.32 & 0.94 & 0.79 & 1.01 & 0.070 & -1.81 \\
Bank N & 0.91 & 0.93 & 0.95 & 1.34 & 1.00 & 1.01 & 0.96 & -0.020 & -2.39 \\
Bank O & 0.98 & 0.93 & 1.00 & 1.27 & 0.91 & 1.14 & 1.02 & 0.004 & -2.31 \\
Bank P & 1.01 & 0.64 & 1.01 & 1.17 & 0.92 & 1.04 & 0.97 & 0.053 & -2.26
\end{tabular}

Note. Researcher disguised the name of sample banks with English Alphabets to maintain the secrecy of transaction.

About Bank H, its DEPI value and M-score values both exceed their optimal demarcation (DEPI as 1.077 and M-score as -2.22) by 2.57 and -1.91 respectively. Beneish (1999) suggests " $A$ DEPI greater than 1 indicates that the rate at which assets are being depreciated has slowedraising the possibility that the company has revised upward the estimates of assets' useful lives or adopted a new method that is income increasing. I thus expected a positive relationship between the DEPI and the probability of manipulation" (p.28). The DEPI value above 1.077 indicates the manipulation by increasing artificially the useful life of its assets. The DEPI value is considerably higher (2.57), concurrently higher value of M-score value (-1.91). This exhibits the approval of the claim of Beneish, i. e. positive relationship between the DEPI and the probability of manipulation. Bank $\mathrm{H}$ is engaging in financial report manipulation via breaching the depreciation provision of its assets.

Taking reference from Bank I, it has LVGI value 1.18 which is greater than LVGI threshold value 1.111. This ratio is used to measure debt over assets of the current year over the previous ones. The bank has an M-score value that is -2.44 which is less than the optimal threshold value of -2.22. It is found; even LVGI is higher the M-score value is below of threshold 
mark. Despite higher leverage, the bank is not practicing fraudulent financial reporting.

Table 3 shows that among 16 banks just 4 banks (Bank G, Bank H, Bank K and Bank M) are responsible for manipulating their financial reports. Even though Bank O, Bank P, Bank L, Bank $J$ and Bank B have higher SGAI but that cannot induce the firm to prepare fraudulent financial reports. On the other hand, Bank $\mathrm{G}$ and Bank $\mathrm{K}$ are engaging in the manipulation of financial reports despite the rational value of DSRI, GMI, AQI, SGI, DEPI, SGAI, LVGI and TATA. Other banks like Bank A, Bank C, Bank D, Bank E, Bank F and Bank N are not practicing fraud reporting behavior simultaneously they have normal DSRI, GMI, AQI, SGI, DEPI, SGAI, LVGI and TATA values.

\section{CONCLUSION}

In conclusion, Bank $\mathrm{H}$ and Bank $\mathrm{M}$ are supposed to be exercising fraudulent financial reporting since those banks have irrational DEPI and GMI values. In other cases, neither of (DSRI, AQI, SGI, SGAI, LVGI, and TATA) values is noticed to be cause for deceptive financial reporting. Similarly, Bank G and Bank K are engaging in income manipulation despite the optimal value of ratio indexes, which exhibits that no ratio indexes are responsible for income misinterpretation. And till the date, the NRB (Nepal Rastra Bank i.e. central bank of Nepal) has not published any incident of financial statement manipulation by respective commercial banks. So, scrutinizing the above data and information Beneish's (1999) M-score model could not be sufficiently supported in detecting financial fraud for private commercial banks listed in NEPSE. This model cannot detect financial fraud in regards to Nepalese financial institutions. The recent research finding is consistent with the finding of Bhavani and Amoinsah (2017), Kukreja et al. (2020), and Lotfi and Chadegani (2017) who advocated the inefficiency of the Beneish model through their research. However, inconsistency in results is observed comparing research work of Kamal, et al. (2016), Maccarthy (2017), Anh and Linh (2016) and Tarjo and Herawati (2015), who identified the Beneish model as a strong detector of financial manipulation.

The major limitation of this research work is that the Beneish model was suggested for manufacturing companies and in the original work of Beneish (1999) financial institutions were excluded from the study, while the recent study explores the model's viability over commercial banks. Beneish (1999) put forward the weaknesses as "one of limitation of the model as it is estimated using financial information for publicly traded companies. Therefore, it cannot be reliably used to study privately held companies. Similarly, the earnings manipulation in the sample involved earnings overstatement rather than understatement; therefore, the model cannot be reliably used to study companies operating in circumstances that are conducive to decreasing earnings" (p.34). A great limitation or the novelty of the present research study is that it explored the suitability of the Beneish model over the banking sectors of Nepal. Despite huge piles of limitations, the present research study could contribute to financial fraud-related literature through the identification of probable earnings manipulation in Nepalese commercial banks which investors prefer the most for their equity investments. The current research results could assist policymakers to apply rigorous exploration on auditing of financial reports of the companies. It can be argued that the results of this research could be encouraging to allow further research into designing a reliable model for detecting fraud in financial statements of companies in Nepal. Similarly, the solvency position and viability of the Beneish model could be tested. The current stock market of Nepal (NEPSE) is observed an abnormal boom in share prices regardless of the Covid pandemic and inactive other economic activities, so if fraudulent financial reporting is responsible for the boom, could be explored in the future. Further research is suggested to test empirically the model considering different industries based on longitudinal data and to answer, does model reflect in reality? 


\section{REFERENCES}

Abdullahi, L. B., \& Ibrahim, S. O. (2017). An evaluation of factors determining earnings management in Nigeria. Amity Global Business Review, 12, 33-45.

Akra, A. M., \& Chaya, J. K. (2020). Testing the effectiveness of Altman and Beneish Models in detecting financial fraud and financial manipulation: Case study Kuwaiti stock market. International Journal of Business and Management, 15(10), 70-81. https://doi.org/10.5539/ijbm.v15n10p70

Albashrawi, M. (2016). Detecting financial fraud using data mining techniques: A decade review from 2004 to 2015. Journal of Data Science, 14, 553-570.https://doi.org/10.6339/JDS. 20160714 (3). 0010

Anh, N. H., \& Linh, N. (2016). Using the M-score model in detecting earnings management: Evidence from non-financial Vietnamese listed companies. VNU Journal of Science: Economics and Business, 32(2), 14-23.

Anning, A. A., \& Adusei, M. (2020). An analysis of financial statement manipulation among listed manufacturing and trading firms in Ghana. Journal of African Business, 1- 15. https://doi.org/10.1080/15228916.2020.1826856

Association of Certified Fraud Examiners. (2020). Association of Certified Fraud Examiners. https://www.acfe.com/report-to-the-nations/2020/.

Beneish, M. D. (1999). The detection of earnings manipulation. Financial Analyst Journal, 55, 24-36.

Beneish, M. D., \& Nichols, C. (2009). Identifying overvalued equity. Johnson School Research Paper Series No. 09-09, https://doi.org/10.2139/ssrn.1134818

Beneish, M. D., \& Nichols, C. (2007). The predictable cost of earnings manipulation. https://doi.org/10.2139/ssrn.1006840

Beneish, M. D., Lee, M. C., \& Nichols, C. (2012). Fraud detection and expected returns. https://doi.org/10.2139/ssrn.1998387

Bhavani, G., \& Amponsah, C. T. (2017). M-score and Z-score for detection of accounting fraud. Accountancy Business and the Public Interest, 68-86.

Chen, C. S. (2016). The effect of mandatory disclosure requirements and disclosure types of auditor fees on earnings management: Evidence from Taiwan. Asia Pacific Management Review, 21(4), 181-195.https://doi.org/10.1016/j.apmrv.2015.12.002

Cressey, D. (1973). Other people's money: A study in the social psychology of embezzlement. Patterson Smith, Montchair, N. J.

Efendi, J., Srivastava, A., \& Swanson, E. P. (2007). Why do corporate managers misstate financial statements? The role of option compensation and other factors. Journal of Financial Economics, 85 (3), 667-708. https://doi.org/10.1016/j.jfineco.2006.05.009

Firth, M., Rui, M. O., \& Wu, W. (2010). Cooking the books: Recipes and cost of falsified financial statement in China. Journal of Corporate Finance, 17(2), 371-390.

Kamal, E. M., Salleh, M. F., \& Ahmad, A. (2016). Detecting financial statement fraud by Malaysian public listed companies: The reliability of the Beneish M-score model. Journal Pengurusan, 46 (2016), 23 - 32.

Kaur, R., Sharma, K., \& Khanna, A. (2014). Detecting earnings management in India: A sectorwise study. European Journal of Business and Management, 6 (11), 11-18.

Kukreja, G., Gupta, S. M., Sarea, A. M., \& Kumaraswamy, S. (2020). Beneish M-score and Altman Z-score as a catalyst for corporate fraud detection. Journal of InvestmeCompliance, 21(4), 231-241. https://doi.org/10.1108/JOIC-09-2020-0022 
Lee, L. F., \& Lo, A. K. (2016). Do opinions on financial misstatement firms affect analysts' reputation with investors? Evidence from reputational spillovers. Journal of Accounting Research, 54, 1111-1148. https://doi.org/10.1111/1475-679X.12119

Lotf, N., \& Chadegani, A. A. (2017). Detecting corporate financial fraud using Beneish M-score model. InternationalJournal of Finance and Managerial Accounting, 2(8), 1-6.

MacCarthy, J. (2017). Using Altman Z-score and Beneish M-score models to detect financial fraud and corporate failure: A case study of Enron Corporation. International Journal of Finance and Accounting, 6(6), 159-166. https://doi.org/10.5923/j.ijfa.20170606.01

Maniatis, A. (2021). Detecting the probability of financial fraud due to earnings manipulation in companies listed in Athens Stock Exchange Market. Journal of Financial Crime. https://doi.org/10.1108/JFC-04-2021-0083

Mantone, P. S. (2013). Using analytics to detect possible fraud: Tools and techniques. Hoboken, New Jersey: John Wiley \& Sons, Inc. ISBN: 978-1-118-71598-7

Occupational fraud and Nepalese scenario. (2020, December 18). Reanda Biz Serve. https://bizserve.com.np/insights/1176/

Omar, N., Koya, R .K., Sanusi, Z. M., \&Shafie, N. A. (2014). Financial statement fraud: A case examination using Beneish model and ratio analysis. International Journal of Trade, Economics and Finance, 5(2), 184-186. https://doi.org/10.7763/IJTEF.2014.V5.367

Orellana, A. R., Romero, M. J., \& Garrido, T. M. (2017). Measuring fraud and earnings management by a case of study: Evidence from an international family business. European Journal of Family Business, 7(1-2), 41-53. https://doi.org/10.1016/ j.ejfb.2017.10.001

Parvin, R. (2020). Earnings management practice in Bangladesh. International Journal of Business and Management Future, 4(1), 27-32. https://doi.org/10.46281/ijbmf.v4i1.492

Perols, J. L., \& Lougee, B. A. (2011). The relation between earnings management and financial statement fraud. Advances in Accounting, incorporating Advances in International Accounting, 27(1), 39-53.

Repousis, S. (2016). Using Beneish model to detect corporate financial statement fraud in Greece. Journal of Financial Crime, 23(4), 1063-1073. https://doi.org/10.1108/jfc-11-2014-0055

Roxas, M. L. (2011). Financial statement fraud detection using ratio and digital analysis. Journal of Leadership, Accountability and Ethics, 8(4), 56-66.

Sridharan, U. V., Caines, W. R., McMillan, J., \& Summers, S. (2002). Financial statement transparency and auditor responsibility: Enron and Andersen. International Journal of Auditing, 6(3), 277-286.

Tarjo, \& Herawati, N. (2017). The comparison of two data mining method to detect financial fraudin Indonesia. Accounting and Finance Review (AFR), 2(1), 18.https://ssrn.com/abstract=3000178

The Kathmandu Post. (2019, December 4). The Kathmandu Post | Read online latest news and articles from Nepal. https://kathmandupost.com/national/2019/12/04/

Warshavsky, M. (2012). Earnings quality. Financial valuation and litigation Expert (FVLE), 39, 16-20.

Wells, J. T. (2017). Corporate fraud handbook: Prevention and detection ( $5^{\text {th }}$ ed.), Wiley. 